University of Louisville

ThinkIR: The University of Louisville's Institutional Repository

$6-1918$

\title{
Simple quantitative determination of the non-protein portion of milk, based on Greenwald's modification of the determination of the non-protein nitrogen in blood.
}

Sarah Huntoon Vance

University of Louisville

Follow this and additional works at: https://ir.library.louisville.edu/etd

\section{Recommended Citation}

Vance, Sarah Huntoon, "Simple quantitative determination of the non-protein portion of milk, based on Greenwald's modification of the determination of the non-protein nitrogen in blood." (1918). Electronic Theses and Dissertations. Paper 1483.

https://doi.org/10.18297/etd/1483

This Master's Thesis is brought to you for free and open access by ThinkIR: The University of Louisville's Institutional Repository. It has been accepted for inclusion in Electronic Theses and Dissertations by an authorized administrator of ThinkIR: The University of Louisville's Institutional Repository. This title appears here courtesy of the author, who has retained all other copyrights. For more information, please contact thinkir@louisville.edu. 
SIMPLE QUANTITATIVE DETERMINATION OF THE NON-PROTEIN PORTION OF MILK, BASED ON GREENWALD'S MODIFICATION OF , THE DETERMINATION OF THE NON-PROTEIN NITROGEN IN BLOOD.

A Thesis Submitted to the Faculty of the College of Arts and Sclences of the

UN I VERS I T Y OF L O U I S V.I L L E Through the Chemlcal Department, In Partial Fulfillment for the Degree

$$
\begin{gathered}
\text { "Master of Sclence," } \\
\text { by }
\end{gathered}
$$

Sarah Huntoon Vance. 
SIMPLE QUANTITATIVE DETERMINATION OF THF NON-PROTEIN PORTION OF MILK, BASED ON GREENWALD'S MODIFICATION OF THE DETERMINATION OF THE NON-PROTEIN NITROGEN IN BLOOD .

As far as I have been able to determine from the scant I1terature at hand, no attempt has been made as yet to determine the percentage of non-protein nitrogen in milk by a procedure simple enough for use as a clinical method. This problem was suggested to me by Dr. Charles J. Robinson, with the request that I should base my method on some of the methods of debermination of the non-protein nitrogen portion of other physiologlcal fluids.

The preparation of protein for milk has been made at various times, both from whole milk and milk powders. Mitchell and ivelson describe a method of preparing a protein for milk using trichloracetic acid as the precitating agent for the proteins.- They made use of milk powder and fifty percent solution of trichloracet1c ac1d. Funk has prepered the pure non-protein nitrogen compounds of $m 11 k$ and other substances by using the alcbholic extract of the dried whole milk. These methods give an 1dea of the character of the work rhich has been done on the non protein nitrogen portion of milk as a whole. Other investigations have been carried out on the determination of individuals coristituents of the non-protein nitrogen portion. 
Method:

The method employed was adopted from Greenwalds trichLoracetic acid method for the determination of the non protein nitrogen in blood. A Solution of $25 \%$ trichloracetic acid was found more satisfactory than one of $2.5 \%$ which Greenwalds suggests for use in determining the non protein nitrogen in blood. Whole cows milk was used throughout the investigation. $50 \mathrm{c} \cdot \mathrm{c}$. whole milk well mixed were diluted in a volumetric flask to $100 \mathrm{c.c}$. w1th $25 \%$ solution of trichloracetic acid.

The flask was shaken well and allowed to stand from fifteen minutes to a half hour or until the precipitate had setiled somewhat. The supernatant liquid was decanted through a dry filter. One c.c. of the filtrate was then treated in a large pena test tube (70cc) with 2 C.C. Sulphite acid; 1 gram of potassium sulphate, powdered; and three drops of $5 \%$ solution of copper sulphate. The mixture was hegted carefully over a burner unt1l clear and then alloved to cool but not solidify. 5-10.c.c. of water were added carefully, and then. the acid solution was made strongly alkaline with about $10 \mathrm{c} . \mathrm{c}$. of \& $33 \%$ sodium bydroxide solution, the ammonia liberated ras asplrated into $2 \mathrm{c} \cdot \mathrm{c} \cdot 1^{\frac{\mathrm{N}}{\mathrm{O}}}$ sulphurdc acld, diluted to $10 \mathrm{c} \cdot \mathrm{c}$. The excess acid was then titrated with $\frac{N}{100}$ or $\frac{N}{50}$ sodium hydroxide. The non protein nitrogen portion was calculated as number of mililgrams of nitrogen per $100 \mathrm{c.c}$. milk. 


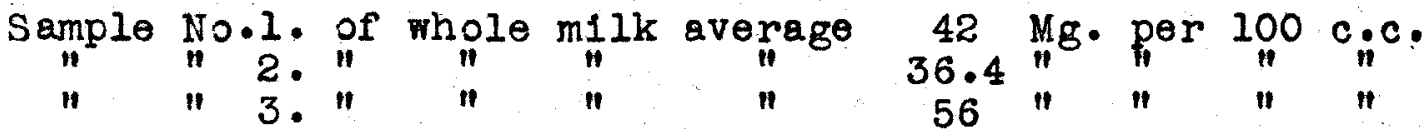

Sample No. 5. Evaporated milk average $35 "$ " " "

\section{Conclusion.}

The non protein nitrogen of whole milk was found to vary from 36 - 56 mililigrams of nitrogen per $100 \mathrm{c.c}$. The nonprotein nitrogen of one sample of evaporated milk undiluted was found to be $70 \mathrm{mg}$. of nitrogen per $100 \mathrm{c} . \mathrm{c}$. The label on the evaporated milk cam suggested diluting with an equal quantity of water to make the product approximately wholo cows milk in composition. In that case, the non protein nitrogen would be $35 \mathrm{milligrams}$ per $100 \mathrm{c.c}$. The significance of the non protein nitrogen containing constituents of milk has. not been determined but various authors have pointed out the presence of substances in milk which come under that class. Funk estimated the vitamine fraction of milk as $C H O N$ and found that there were. I - .25 milligrams of vitamine nitrogen per $100 \mathrm{c.c}$. of milk. If the residue of non protein nitrogen be considered as allantoin, there would be $2-5 \mathrm{mg}$. of allantion nitrogen per $100 \mathrm{coc}$ of milk. Urea in fresh m11k has been determined as $18 \mathrm{mg}$ of urea nitrogen per $100 \mathrm{c} \cdot \mathrm{c}$. The amount of creatine and creatime, and the purine bases, ademine and guanine have been found not to exceed a fen miligrams of the non protein nitrogen per $100 \mathrm{c.c}$. The ammonia in fresh milk has been estimated as 0.3 - 0.4 milifigrams per $100 \mathrm{c} . \mathrm{c}$ of milk. 
The sum total of these figures 21 - 25 milligrams of nitrogen per $100 \mathrm{c.c}$. does not total the number of milligrams of non protein as determined by the above method. However the lecithin nitrogen as well as the amino acid nitrogen has not been determined.

It is interesting to note that the number of mili1grams of non protein nitrogen per 100 c.c. of milk determined by the above method very closely approximated the amount of non protein nitrogen per $100 \mathrm{c} . \mathrm{c}$. of blood determined by Greenwald's method.

(1) Nitchell and Nelson, Uni. Ill. B10l. Chem 23. $459-67$ (1915)

(2) Funk

(3) Greenwalds J. B101. Chem. 21, 61, 1915.

(4) Funk, London B101. Chem. J. 7,211,3.

(5) Jour. B101 Chem. $17-475.81$.

(6) Spittgerlar - Rilfart Ze1t. Natur. Genus . 27,59,67.

(7) "Our Pet" Brand Evaporated milk.

- Helvatia Milk Condensing $C_{0}$, Highland, III. U.S.A. 